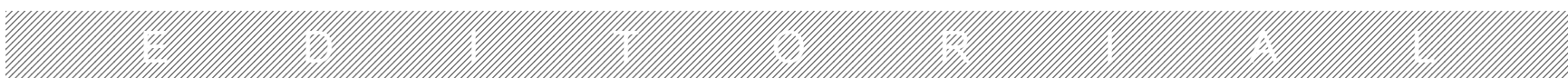

\title{
Assumindo a Editoria
}

No outono de 2001, fins do meu primeiro ano de doutorado, Oswaldo Yamamoto sinalizou-me a possibilidade de realização de um curso chamado "Editor do Futuro", que seria oferecido pela Associação Brasileira de Editores Científicos (ABEC). Ao fazer o curso, naquele momento, não tinha a pretensão de assumir a editoria de um periódico. Fato é que, passados oito anos do meu primeiro contato com os meandros do trabalho cotidiano em uma revista científica, nesse número que inicia o volume 14 da Estudos de Psicologia (Natal), assumo a árdua e gratificante função de editora.

A minha trajetória na revista é relativamente longa. Foram anos auxiliando Oswaldo e, posteriormente, José Pinheiro. Eles muito me ensinaram a respeito da importância de estruturar um excelente meio de divulgação do conhecimento produzido pela Psicologia e áreas de interlocução: os cuidados com os manuscritos, o sigilo das informações, a difícil tarefa da escolha de consultores, a administração dos prazos a cumprir (sempre exíguos!); enfim, um sem número de responsabilidades que agora assumo integralmente. Passei de assistente de editoração a editora adjunta e associada. Contei com a colaboração e apoio de colegas como Márcio Capriglione, Jorge Falcão e Symone Melo. Por fim, mas não menos importante, pude contar com o apoio dos vários secretários que passaram pela revista, cujo trabalho foi e é imprescindível para a manutenção do nosso padrão de qualidade. Nesse caminho, agradeço especialmente a Soraya Souza, nosso apoio editorial atual, profissional de qualidade excepcional e a quem devo muito, principalmente pelo suporte na condução do cotidiano da revista.

Em função dessa experiência, conheço bem as dificuldades do trabalho e as intercorrências por que passou a Estudos de Psicologia nesses 14 anos de existência. Exatamente por isso, me senti impelida a aceitar a função de editora, dispondo-me a investir esforços na manutenção de uma revista de tal porte, sediada numa universidade do nordeste brasileiro, feita às custas do esforço de alguns pesquisadores que acreditavam ser possível melhorar os padrões de divulgação do conhecimento produzido na área, cuja importância no cenário acadêmico nacional é consolidada e reconhecida. Agradeço a todos os que me confiaram essa tarefa e espero desempenhá-la da melhor forma. Especialmente, agradeço a Symone Melo e Fívia Lopes, pela disponibilidade em continuar a contribuir no gerenciamento da Estudos de Psicologia (Natal), agora como editoras associadas.

Além da editoria, o volume 14 da Estudos de Psicologia apresenta outras mudanças. Delineamos uma nova política editorial com vistas a um melhor direcionamento dos manuscritos que nos chegam. Tais mudanças, embora só se concretizem no volume 15 , já se começam a implementar desde já e estão detalhadas no site da Estudos de Psicologia (Natal).

A primeira delas diz respeito a alterações nas normas e condições de submissão de manuscritos. Tentando elevar, ainda mais, o nosso padrão de qualidade, a partir do próximo volume estaremos mais rigorosos quanto aos requisitos necessários para que os manuscritos submetidos iniciem a tramitação.

Uma alteração significativa para a comunidade científica que acessa a nossa revista é o novo formato. Os fascículos passarão a ser compostos, preferencialmente, por uma seção geral de 10 manuscritos e por um dossiê temático com outros 10. Desse modo, continuaremos a receber manuscritos das diversas áreas da Psicologia e faremos, gradativamente, a divulgação dos detalhes a respeito de cada dossiê. Aos autores com manuscritos já em tramitação na Estudos de Psicologia (Natal), esclarecemos que estes serão processados sob as normas vigentes até então.

Ainda relatando as novidades, há uma nova Comissão Editorial e um Conselho Científico em composição. Agradeço a participação e contribuição de todos os que nos auxiliaram durante o tempo em que estiveram nas respectivas instâncias e o esforço para manter a Revista nos melhores padrões de qualidade. Aos que chegam, conto com a ajuda e espero disposição para o trabalho!

Um bom aproveitamento do fascículo 14.1 a todos que o buscarem.

Isabel Fernandes Editora 